\title{
A new macrofossil ephedroid plant with unusual bract morphology from the Lower Cretaceous Jiufotang Formation of northeastern China
}

Yong Yang ${ }^{1 *}$, Yingwei Wang ${ }^{2}$ and David Kay Ferguson ${ }^{3}$

\begin{abstract}
Background: The evolution of the Jehol Biota of western Liaoning in China includes three phases, initiation in the Dabeigou phase, radiation in the Yixian phase, and decline in the Jiufotang phase. Numerous ephedroid macrofossils were reported from the Lower Cretaceous Yixian Formation. However, so far none has been found in the younger Jiufotang Formation (ca. 120.3 Ma) of western Liaoning.

Results: Here we report a new species Jianchangia verticillata gen. et sp. nov. with unusual morphology from the Lower Cretaceous of the Jiufotang Formation, Lamadong Village, Jianchang County, Liaoning. This species is the first record of gnetophytes from the Jiufotang Formation. It is similar to other ephedroid species from the Yixian Formation in possessing linear leaves with parallel veins, jointed shoots with swollen nodes and longitudinally furrowed internodes, and ovulate cones possessing two whorls of bracts enclosing two chlamydosperms, but differs from all known species by the ovulate cone having multiple fine linear verticillate bracts.
\end{abstract}

Conclusions: This study expands our knowledge about the diversity of early gnetophytes in the Lower Cretaceous, and demonstrates the lineage continuity of gnetophytes from the Yixian Formation to the younger Jiufotang Formation.

Keywords: China, Diversity, Ecology, Evolution, Ephedraceae, Gnetophytes, Jiufotang Formation, Lower Cretaceous

\section{Background}

Modern gnetophytes consist of three monogeneric families: Ephedraceae (Ephedra L., 60 spp.), Gnetaceae (Gnetum L., 44 spp.), and Welwitschiaceae (Welwitschia Hook. f., 1 sp.) [1]. The three living families possess divergent characters: Ephedraceae are usually dichasially branched shrubs, rarely small trees or lianas, possess linear parallelveined leaves at the swollen nodes, compact ovulate cones with only one distal pair/whorl of fertile bracts, and are distributed in cold and arid places; Gnetaceae are commonly lianas, rarely small trees, possess pinnately veined broad leaves at the swollen nodes, and ovulate spikes with multiple loosely arranged fertile bract collars, and occur in

\footnotetext{
* Correspondence: ephedra@ibcas.ac.cn

${ }^{1}$ State Key Laboratory of Systematic and Evolutionary Botany, Institute of Botany, Chinese Academy of Sciences, Beijing 100093, China

Full list of author information is available at the end of the article
}

tropical/subtropical evergreen forests; while Welwitschiaceae are short and unbranched plants, have ovulate cones with many pairs of fertile bracts, have two giant persistent leaves with multiple parallel veins connected by crossveins, and are restricted to arid coastal areas of southwestern Africa [1-9].

Despite their divergence, these plants consistently bear a unique chlamydosperm, i.e. one or two outer envelopes enclosing an inner ovule with the integument elongated beyond the envelope into a micropylar tube [10-16]. This unusual structure is different from the naked ovule in cycads, Ginkgo L., conifers, and from the angiospermous ovule completely enclosed within a closed carpel, thus displaying a seemingly transitional morphology between angiosperms and other groups of gymnosperms. Recent phylogenetic/genomic/phylotranscriptomic studies have suggested that the gnetophytes

(c) The Author(s). 2020 Open Access This article is distributed under the terms of the Creative Commons Attribution 4.0 International License (http://creativecommons.org/licenses/by/4.0/), which permits unrestricted use, distribution, and reproduction in any medium, provided you give appropriate credit to the original author(s) and the source, provide a link to the Creative Commons license, and indicate if changes were made. The Creative Commons Public Domain Dedication waiver (http://creativecommons.org/publicdomain/zero/1.0/) applies to the data made available in this article, unless otherwise stated. 
are sister to the Pinaceae, i.e. the gnepine hypothesis [17-20], though conflicting results have been reported [21-23].

Palaeobotanical studies are promising because early fossils are filling gaps between these morphologically isolated families. Many gnetalean macrofossil plants have been reported from the Lower Cretaceous in Australia [24], Europe [25, 26], North America [25-28], South America [29-37], and particularly the Yixian Formation of western Liaoning, northeastern China [15, 38-54]. These fossil plants display a wide range of morphological diversity including leaf/bract and cone morphology, and are important in evolutionary studies of the early gnetophytes. Previously reported fossils are mainly from the Jianshangou Bed (ca. $125 \mathrm{Ma}$ ) of the Yixian Formation $[55,56]$, but none from younger strata such as the Jiufotang Formation (ca. 120.3 Ma) [57]. The evolution of the Jehol Biota consists of three phases, i.e. initiation during the Dabeigou phase, radiation in the Yixian phase, and decline in the Jiufotang phase [57]. Almost all known Cretaceous gnetalean fossils in northeastern China were found in the Yixian Formation. Any fossils from the Dabeigou phase and the Jiufotang phase would be interesting because they might provide some clues on the evolution and ecology of early gnetophytes.

Here we describe a new macrofossil plant from the Jiufotang Formation, and note that this species possessed certain unusual characters which distinguish it from all other known ephedroid species from the Jianshangou Bed.

\section{Results}

Gymnosperms

Subclass - Gnetidae

Order - Ephedrales

Family - Ephedraceae Dumortier

Genus - Jianchangia Y. Yang, Y.W. Wang \& D.K. Ferguson, gen. nov.

Diagnosis - Fossil genus showing ephedroid morphology similar to Gurvanella, Callianthus, Beipiaoa, and Ephedra in having an articulated shoot with swollen nodes, longitudinally furrowed internodes, foliar organs having two parallel veins, and a compact ovulate cone having a pair of chlamydosperms, but distinguished by having linear bracts inserted in whorls.

Etymology - After the county name of the type locality, Jianchang.

Type Species - Jianchangia verticillata Y. Yang, Y.W. Wang \& D.K. Ferguson, sp. nov., Figs. 1, 2 and 3

Diagnosis - Ovulate cones sessile or subsessile; each possessing two whorls of bracts and two chlamydosperms;

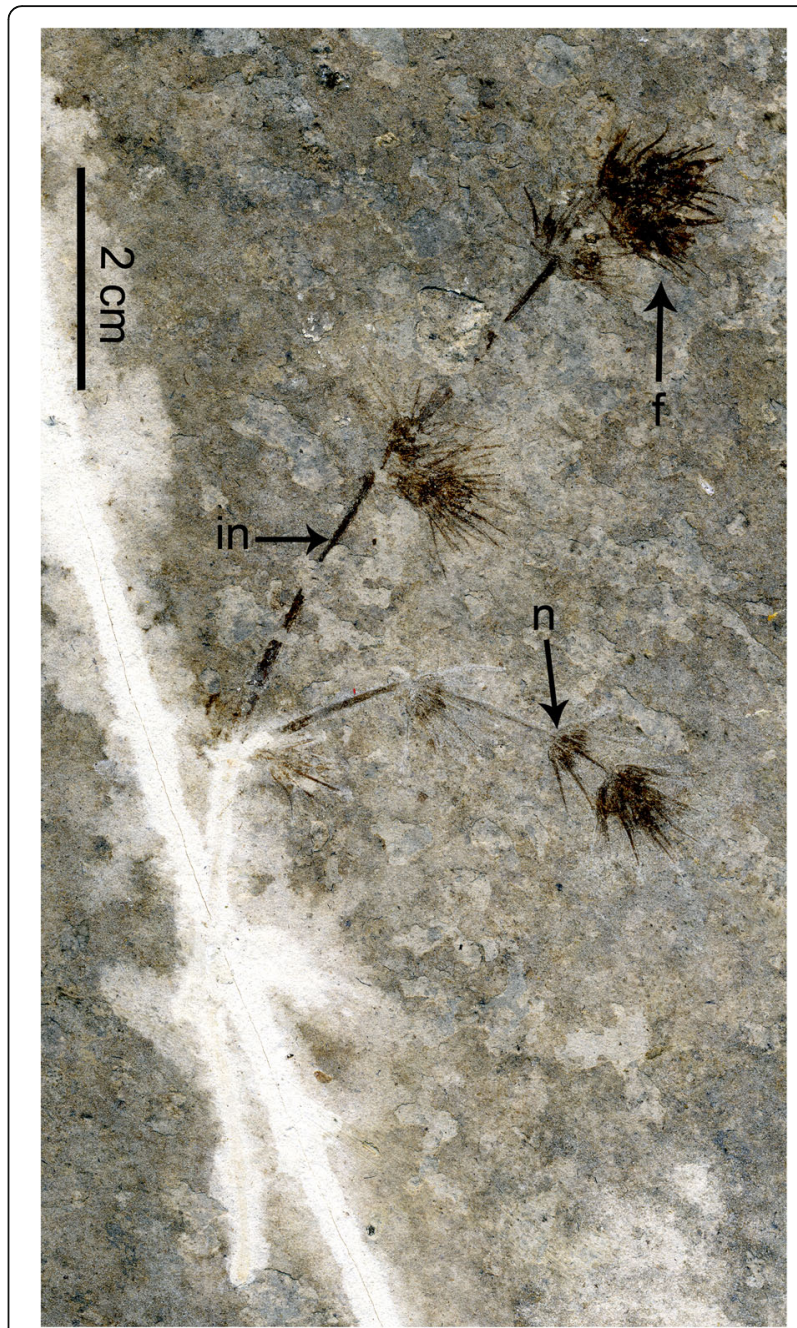

Fig. 1 Type specimen of Jianchangia verticillata gen. et sp. nov. displaying the general morphology of the species. Abbreviations: in, internode; $\mathrm{n}$, node; $\mathrm{f}$, ovulate cone

bracts leaf-like, linear-lanceolate, parallel-veined, ascending; chlamydosperms ca. $1.8 \mathrm{~mm}$ long, $1.5 \mathrm{~mm}$ wide.

Description - A single impression specimen with no counterpart showing a portion of a reproductive branch, ca. $9.1 \mathrm{~cm}$ long, ca. $1 \mathrm{~mm}$ thick but thinner distally, and the main branch with four nodes and one lateral branch. Internodes becoming shorter apically, basal internode ca. $3.9 \mathrm{~cm}$ long, next internode ca. $2.4 \mathrm{~cm}$ long, third internode ca. $2.1 \mathrm{~cm}$ long, fourth internode (or peduncle of an ovulate cone) ca. $0.6 \mathrm{~cm}$ long, and uppermost internode very short. Basal lateral branch $\mathrm{ca} .3 .2 \mathrm{~cm}$ long, and possessing four nodes, internodes becoming shorter distally, ca. $1.4 \mathrm{~cm}, 1.1 \mathrm{~cm}$, and $0.5 \mathrm{~cm}$ long from the proximal to the distal, uppermost internode very short. Internodes possessing fine longitudinal striations (Figs. 1 and 2a). Ovulate cones sessile or sub-sessile and paired at each node (Figs. 1 and 2b). Each ovulate cone containing two whorls of bracts; four or more bracts at each 

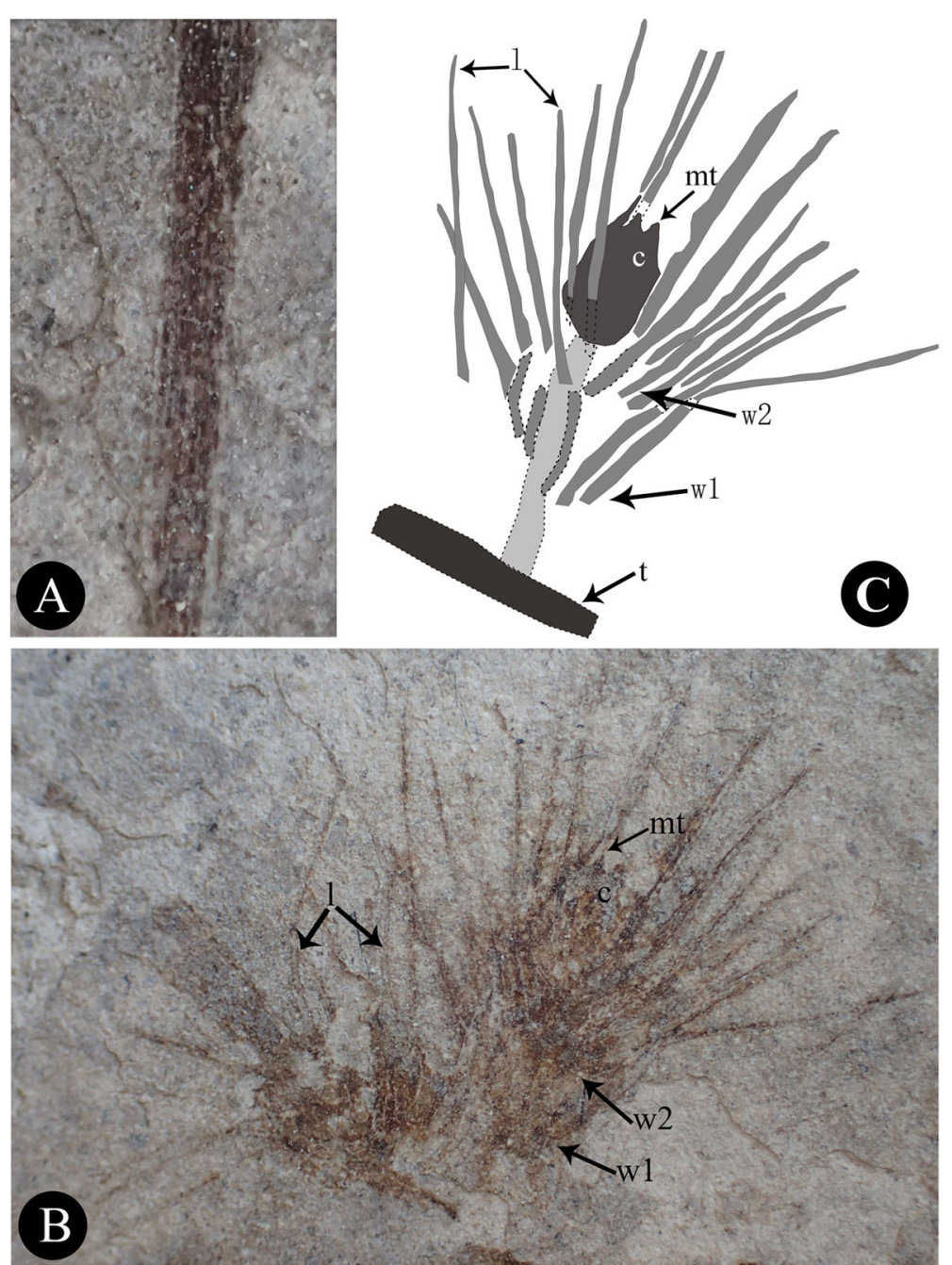

Fig. 2 Morphological details of Jianchangia verticillata gen. et sp. nov. a a stem portion displaying the multiple longitudinal striations; $\mathbf{b}$ ovulate cones displaying the two whorls of linear bracts and the enclosed chlamydosperms; c diagram of an ovulate cone in (b) displaying structural details. Abbreviations: I, parallel-veined leaves/bracts; mt, micropylar tube; w1, the proximal whorl of bracts; w2, the distal whorl of bracts

node, linear, ascending. Two chlamydosperms enclosed within the uppermost whorl of bracts; obovoid, ca. 1.8 $\mathrm{mm}$ long, $1.5 \mathrm{~mm}$ wide, and narrowing towards the apex into a short tube (Fig. 2b).

Distribution - This species is only known from Lamadong Village, Jianchang County, Huludao Municipality, Liaoning of northeastern China.

Holotype - PE2018013101 (Fig. 1), deposited in the National Museum of Plant History of China, Institute of Botany, Chinese Academy of Sciences, Beijing.

Etymology - 'Verticillata' refers to the whorled linear bracts of the new species.

Stratigraphic age and horizon - Early Cretaceous (Aptian, ca. 120.3 Ma), Jiufotang Formation.

Remarks - Gnetophytes are common floristic elements in the Lower Cretaceous. They have been found in Europe, North America, South America, Australia, and northeastern Asia including Mongolia and northeastern China [25, 26, 30, 35, 38, 39, 41, 46, 47, 53]. The richest diversity is in the Yixian Formation [16]. Previous findings of ephedroid plants in northeastern China are restricted to Yixian and Lingyuan Counties, Liaoning Province. The new species described here was discovered in Jianchang County, Liaoning Province, China. This locality belongs to the Jiufotang Formation, which is younger than the Yixian Formation $[55,56]$.

The unique character of our new species lies in the number of foliar organs at the nodes. Though leaves/ bracts are linear and possess two parallel veins as in many other gnetophyte species from the Yixian Formation, four or more of them are whorled at the nodes. The ovulate cones possess two whorls of bracts that are ascending and free from one another. There are two chlamydosperms enclosed in the uppermost whorl of 


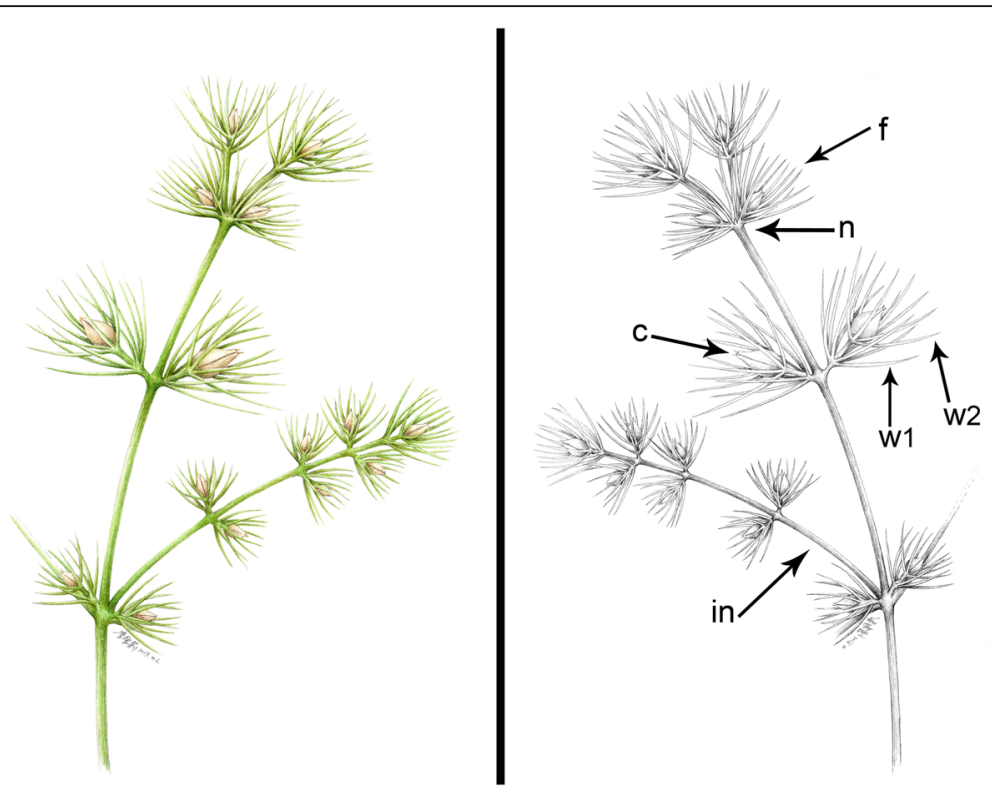

Fig. 3 Reconstruction of Jianchangia verticillata gen. et sp. nov., displaying important characters. Abbreviations: c, chlamydosperms; f, ovulate cone; in, internode; n, node; w1, the proximal whorl of bracts; w2, the distal whorl of bracts

bracts, which shows similarity to Gurvanella, Callianthus, Beipiaoa, and Ephedra [41, 46, 47, 51, 58]. These genera are classified based on their bract morphology (Figs. 4a-c). Our new species shows unusual bract morphology different from these known genera. As a result, we established a new genus here to include the new species based on the current classification of the ephedroid plants.

A one to one relationship between chlamydosperm and its subtending bract is relatively stable in ephedroid plants excepting Siphonospermum, in which chlamydosperms are pedicelled and have no associated bracts [45]. A chlamydosperm is axillary to a subtending bract and a pair of fertile bracts usually enclose two chlamydosperms in an ovulate cone. Sometimes, the paired bracts enclose only a single chlamydosperm because of abortion, e.g. E. monosperma and E. nebrodensis. The unusual feature of our new genus is that the multiple verticellate bracts enclose only two chlamydosperms in an ovulate cone, which fundamentally breaks the rule of chlamydosperm-bract relationship in Ephedraceae. There are two explanations for this pattern: the first is that the multiple bracts in a whorl are derived by division of two bracts, so there are only two chlamydosperms; the second is that the bracts are primary, but the original multiple chlamydosperms are reduced to only two due to loss. We are inclined to
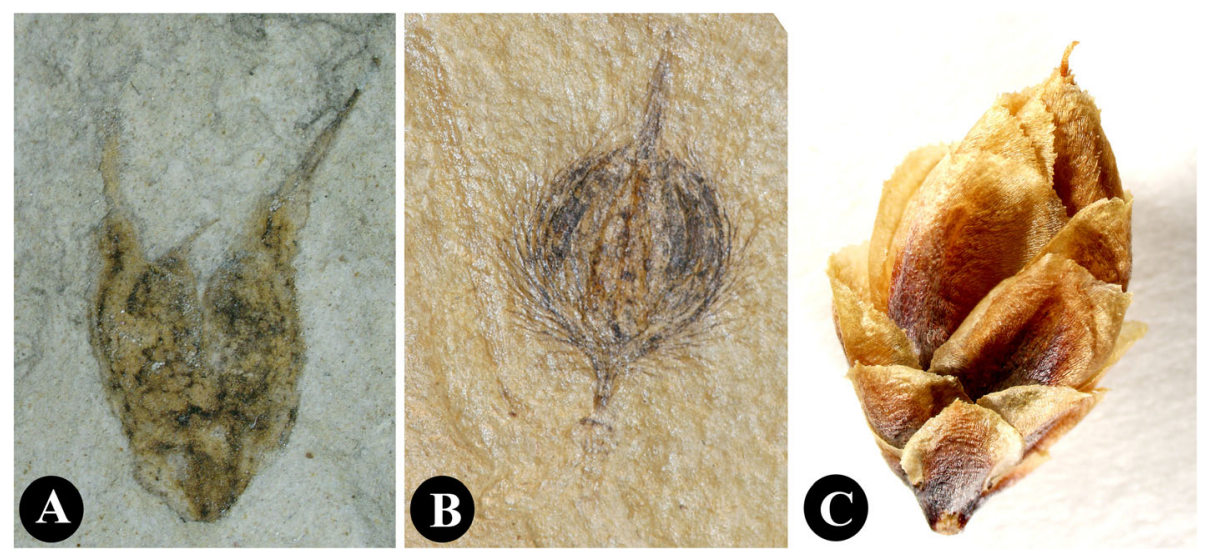

Fig. 4 Ovulate cones displaying variation of bracts in genera related to Jianchangia gen. nov. a Beipiaoa spinosa Dilcher \& al. displaying spinose bracts; b Gurvanella dictyoptera Krassilov displaying a bract having many furcate veins, c Ephedra torreyana S. Watson displaying obtuse bracts 
the first explanation, and believe that the multiple bracts of the same whorl may have been divided/ multiplied from two bracts, since opposite phyllotaxis is predominant and presumably ancestral in the gnetophytes.

\section{Discussion}

\section{Variation of leaves of early ephedroid plants}

Ephedroid plants from the Yixian Formation display a great diversity of leaf morphology. Many of them possess linear and opposite leaves with parallel veins, e.g. Liaoxia cheniae (Wu \& Guo) Rydin \& al. [46], Ephedra hongtaoi Wang \& Zheng [49], Siphonospermum simplex Rydin \& Friis [45], Chengia laxispicata Y. Yang \& al. [16], Protognetella minuta Krassilov [15], Liaoningia decussata Y. Yang \& al. [59], but variation does occur. In Spinobractea lanceolata H.M. Liu \& al. [43] and Constrobilus ovata H.M. Liu \& al. [43], the leaves are broad and petiolate and have furcate-pinnate venation. In Latibractea divisa H.M. Liu \& al. [43], the leaves are petiolate and divided and seem to be compound. In Ephedra multinervia Y. Yang \& al., the leaves are strap-shaped and elongate and have multiple parallel veins connected by cross-veins, similar to those of Welwitschiaceae [52]. Jianchangia verticillata possesses normal ephedroid leaf shape, i.e. linear and parallel-veined, but is distinct from all known gnetalean fossils in that the foliar organs are verticellate.

\section{Morphological diversification of bracts of early ephedroid plants}

Representative types of ephedroid ovulate cones are illustrated in Fig. 5; a comparison between Jianchangia and related fossils from northeastern China is provided in Tables 1 and 2. Jianchangia shows similarities to other known early ephedroid plants from northeastern China in the linear and parallel-veined leaves and the articulate reproductive shoots with swollen nodes and fine longitudinal striations. Siphonospermum simplex differs from all known ephedroid plants [16] in having no typical ovulate cones or spikes, the chlamydosperms being pedicelled and lacking subtending bracts/leaves [45]. Pseudoephedra was reported as incertae sedis [44], but may be related to Siphonospermum in that it shows general ephedroid morphology, and the chlamydosperms are pedicelled and not closely associated with any foliar organs. Jianchangia differs from Siphonospermum and Pseudoephedra in the presence of ovulate cones and the whorled bracts subtending the inner paired chlamydosperms.

Protognetum is a Jurassic macrofossil that also possesses ephedroid vegetative morphology and ovulate spikes; the bracts are linear and leaf-like, but at each node there are only two bracts subtending a whorl of chlamydosperms; these characters indicate its relationship to the Gnetaceae clade [1]. Our new fossil genus Jianchangia can be easily distinguished from Protognetum by the fact that the whorled bracts subtend only two chlamydosperms. Spinobractea has

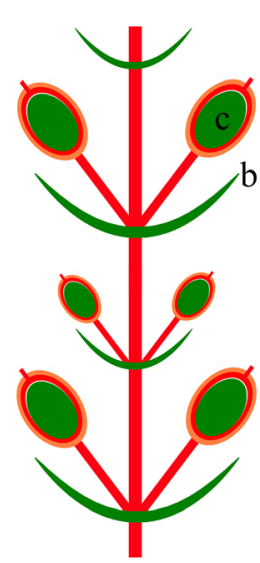

A

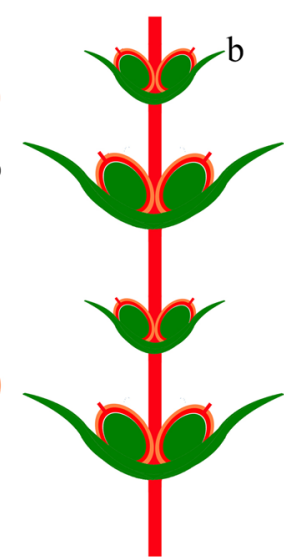

B

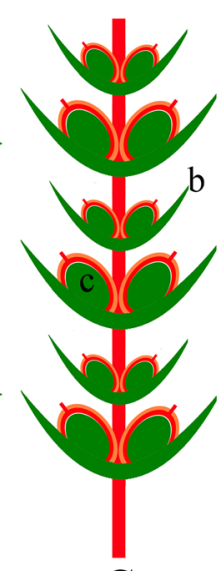

C
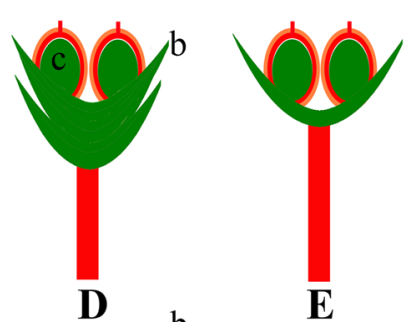

D

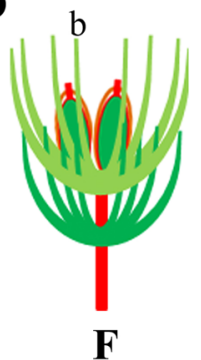

Fig. 5 Illustrations of representative types of ovulate cones of ephedroid plants. A, Siphonospermum, reproductive shoot with pedicelled chlamydosperms; B, Prognetella, reproductive shoot with axillary and sessile chlamydosperms subtended by elongate leaf-like bracts; C, loosely arranged ovulate spike of Chengia and Liaoningia with shortened internodes and modified bracts; D, ovulate cone of Ephedra with a few pairs of proximal modified sterile bracts and a distal pair of modified fertile bracts, each modified fertile bract subtending an axillary and sessile chlamydosperm; E, ovulate cone of Gurvanella and Beipiaoa with one apical pair of modified fertile bracts, each subtending an axillary and sessile chlamydosperm; F, Jiangchangia, ovulate cone with two whorls of leaf-like bracts enclosing two sessile chlamydosperms 


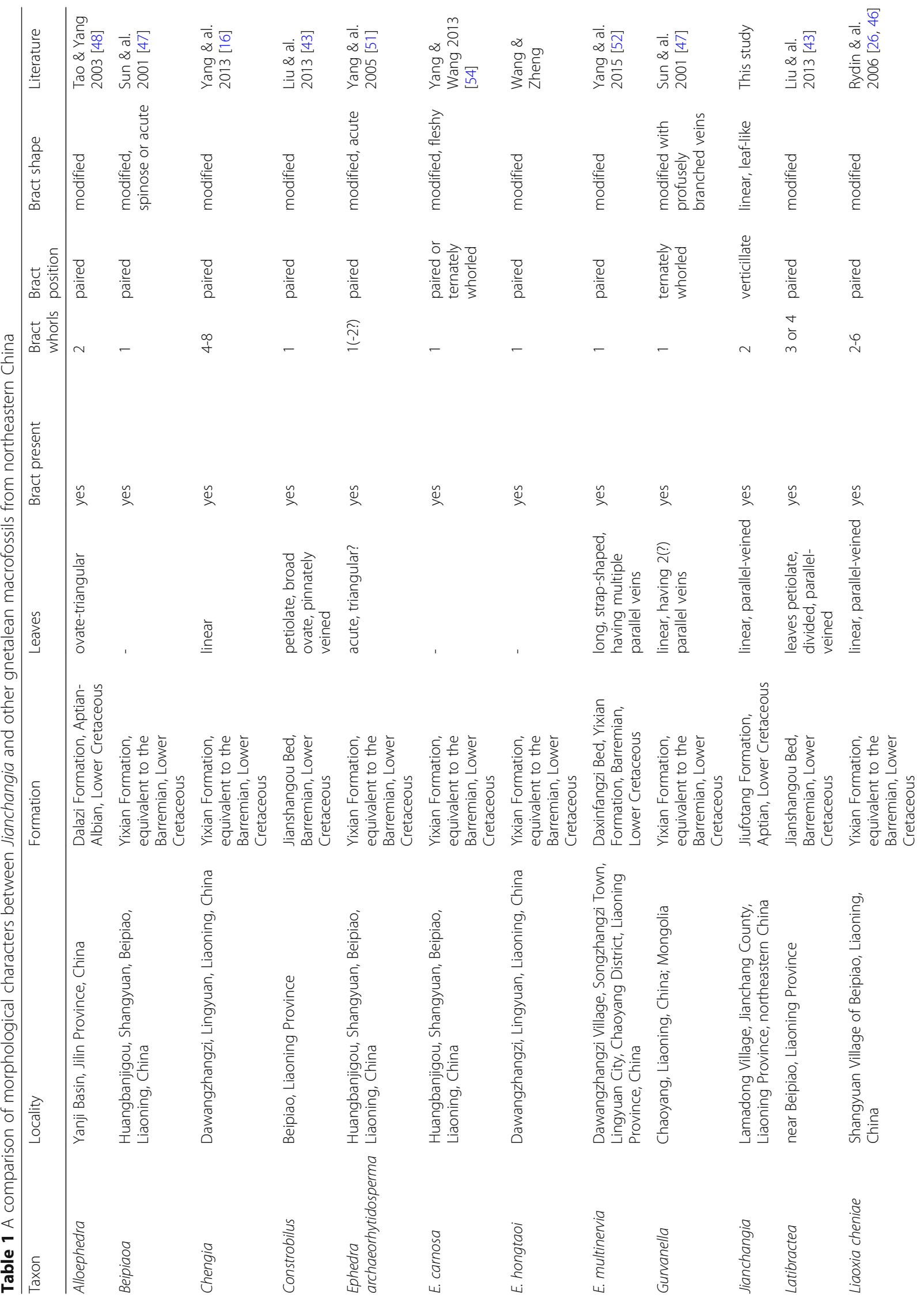




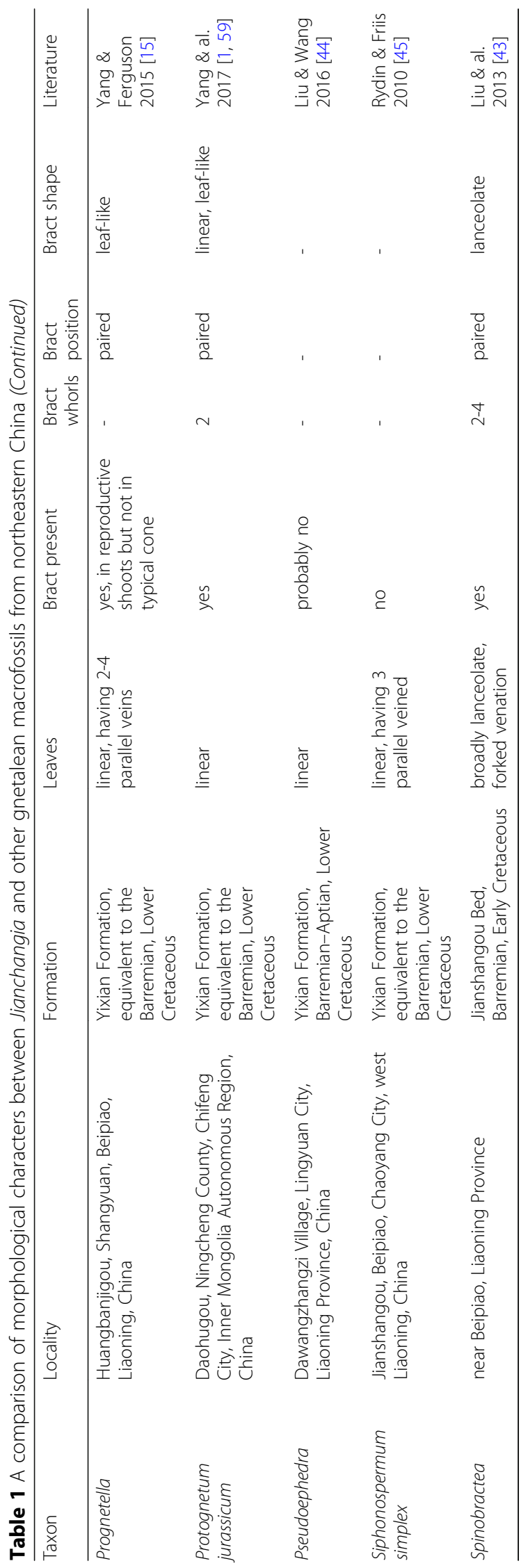


Table 2 A comparison of morphological characters between Jianchangia and other gnetalean macrofossils from northeastern China

\begin{tabular}{|c|c|c|c|c|c|}
\hline Taxon & $\begin{array}{l}\text { Female cone } \\
\text { present }\end{array}$ & $\begin{array}{l}\text { Chlamydosperms } \\
\text { pedicled }\end{array}$ & $\begin{array}{l}\text { Chlamydosperms } \\
\text { in a cone }\end{array}$ & $\begin{array}{l}\text { Chlamydosperms } \\
\text { sculptured }\end{array}$ & Literature \\
\hline Alloephedra & yes, compact & no & 2 & no & Tao \& Yang 2003 [48] \\
\hline Beipiaoa & yes, compact & no & 2 & no & Sun \& al. 2001 [47] \\
\hline Chengia & $\begin{array}{l}\text { yes, but laxly } \\
\text { arranged into spikes }\end{array}$ & no & Many in multiple whorls & no & Yang \& al. 2013 [16] \\
\hline Constrobilus & yes, compact & no & 2 & no & Liu \& al. 2013 [43] \\
\hline $\begin{array}{l}\text { Ephedra } \\
\text { archaeorhytidosperma }\end{array}$ & yes, compact & no & $1-2$ & $\begin{array}{l}\text { transversely } \\
\text { wrinkled }\end{array}$ & Yang \& al. 2005 [51] \\
\hline E. carnosa & yes, compact & no & $1-3$ & no & Yang \& Wang 2013 [54] \\
\hline E. hongtaoi & yes, compact & no & 2 & no & Wang \& Zheng \\
\hline E. multinervia & yes, compact & no & 2 & no & Yang \& al. 2015 [52] \\
\hline Gurvanella & yes, compact & no & usually 3 & no & Sun \& al. 2001 [47] \\
\hline Jianchangia & yes, compact & no & 2 & no & This study \\
\hline Latibractea & yes, compact & no & - & - & Liu \& al. 2013 [43] \\
\hline Liaoxia cheniae & yes, compact & no & many & no & Rydin \& al. 2006 [26, 46] \\
\hline Prognetella & $\begin{array}{l}\text { no, in reproductive } \\
\text { shoots }\end{array}$ & no & $\begin{array}{l}\text { paired at nodes of } \\
\text { reproductive shoots }\end{array}$ & no & Yang \& Ferguson 2015 [15] \\
\hline $\begin{array}{l}\text { Protognetum } \\
\text { jurassicum }\end{array}$ & laxly arranged spikes & no & $\begin{array}{l}4-6 \text { whorled at nodes of a } \\
\text { reproductive shoot }\end{array}$ & no & Yang \& al. $2017[1,59]$ \\
\hline Pseudoephedra & no & yes & not organized into a cone & no & Liu \& Wang 2016 [44] \\
\hline $\begin{array}{l}\text { Siphonospermum } \\
\text { simplex }\end{array}$ & no & yes & pedicled & no & Rydin \& Friis 2010 [45] \\
\hline Spinobractea & $\begin{array}{l}\text { yes, more or less in } \\
\text { lax spikes }\end{array}$ & no & $1-2$ & no & Liu \& al. 2013 [43] \\
\hline
\end{tabular}

ovulate spikes with multiple pairs of bracts that appear to be elongate and strap-shaped [43], characters which are different from the whorled linear bracts enclosing only two chlamydosperms in Jianchangia. Gnetum possesses ovulate spikes with multiple whorls of chlamydosperms, with each whorl subtended by a collar of bracts, while Welwitschia has ovulate cones with multiple pairs of fertile bracts each subtending an axillary chlamydosperm. The circular and paired bracts in Gnetum and Welwitschia distinguish them from our new genus.

Jianchangia is also similar to a few other macrofossils from the Lower Cretaceous Yixian Formation in its ephedroid vegetative morphology and presence of bracts in ovulate spikes/cones, e.g. Prognetella Krassilov [15], Chengia Y. Yang \& al. [16], Liaoningia Y. Yang \& L.B. Lin [59], and Liaoxia Cao \& Wu [46], but differs from all of them in having only one fertile whorl in each ovulate cone (vs. multiple fertile pairs/whorls in each ovulate cone in the latter five genera) in addition to fine, linear bract morphology. In Prognetella, the bracts are usually elongate and leaf-like, only modified at the basal portion to subtend the partially enclosed chlamydosperms [15], whereas the bracts of Jianchangia are not modified and are organized into whorls and not pairs. In
Liaoningia, Chengia, and Liaoxia, the bracts are modified and not leaf-like, and paired at the nodes. Jianchangia differs from all of them in having unspecialized bracts arranged into whorls.

Jianchangia is similar to Gurvanella Krassilov [41], Beipiaoa Dilcher \& al. [47], and Ephedra in having ovulate cones with only one fertile whorl in addition to the ephedroid vegetative morphology, but differs from the latter genera mainly in having unspecialized and verticillate bracts $[35,40,47,49,51,52,54]$. In Gurvanella, the two to three bracts are specialized in shape and possess unusual furcate venation [47], which makes it easily distinguished from Jianchangia. In Beipiaoa and Ephedra, the bracts are also modified but only two or three are inserted at each node [47]. This is also the case in Erenia Krassilov and Callianthus Wang \& Zheng, in which the bracts are not leaf-like but specialized and encapsulate a pair of chlamydosperms [58]. Constrobilus and Latibractea probably belong to this complex because both of them have ovulate cones with one pair of chlamydosperms, as in modern Ephedra, but their leaves are unusual, divided in Latibractea and broad and pinnately veined in Constrobilus [43]. The differences between Jianchangia and these two genera are 
obvious, the bracts of the latter two genera are specialized and paired, thus differing from the leaf-like and whorled bracts in Jianchangia.

In summary, bracts of these ephedroid macrofossils show intergrading modifications from absence to presence, and from leaf-like to specialized shape. These transformations together with the reduction of the fertile whorls of the ovulate spike may reflect the evolutionary stages and probable relationships among them, but phylogenetic analysis is needed to test the direction of these transformations.

There are a few other reported gnetalean fossils, but unfortunately we cannot compare them with our new fossil genus because these plants are either pollenproducing, e.g. Khitania Guo \& al. [38] and Eamesia Y. Yang \& al. [53], or they are mesofossil seeds/chlamydosperms with no diagnostic characters of bracts and ovulate cones, e.g. Ephedra drewriensis Rydin \& al. [26], E. portugallica Rydin \& al. [26]., and Bicatia Friis \& al. [25].

\section{Ecology}

Modern Ephedra usually lives in dry areas, in Gobi-type deserts (e.g. E. rhytidosperma Pachom., Fig. 6a), on cliffs (e.g. E. equisetina Bunge, Fig. 6b), or in stony crevices (e.g. E. monosperma Gmel. ex C.A. Mey., Fig. 6c), and they are distributed from Mediterranean regions eastwards to Siberia and northern China, in southwestern U.S.A. and northwestern Mexico, and Andean South America as well [60]. Early ephedroid plants may have occupied more diverse habitats than they do now, probably also in humid swampy places [15], and even in water [49], and these plants evolved a set of characters adapted to the palaeoenvironment. Prognetella is provided with an unusual set of characters, for instance, the fragmented reproductive shoots and frequent cystiform chlamydosperms may have facilitated the dispersal of diaspores in a lacustrine environment [15]. Our new species displays leaf/bract morphology distinct from other species of the Yixian Formation and extant species, which may represent an ecological adaptation. The numerous fine linear leaves of Jianchangia may be functionally analogous to the finely divided leaves of many living species of aquatic flowering plants, e.g. Myriophyllum spicatum L. and Hippuris vulgaris L. [61, 62].

Three phases of floristic development were recognized for the Jehol Biota, i.e. the early initiation Dabeigou phase, the middle radiation Yixian phase, and the late declining Jiufotang phase [57]. There are only a few plant fossils of gymnosperms recorded from the Jiufotang Formation, e.g. Ginkgoites truncatus Li, Czekanowskia rigida Heer, and Elatocladus pinnatus Sun \& Zheng. All three plants were also recorded from the

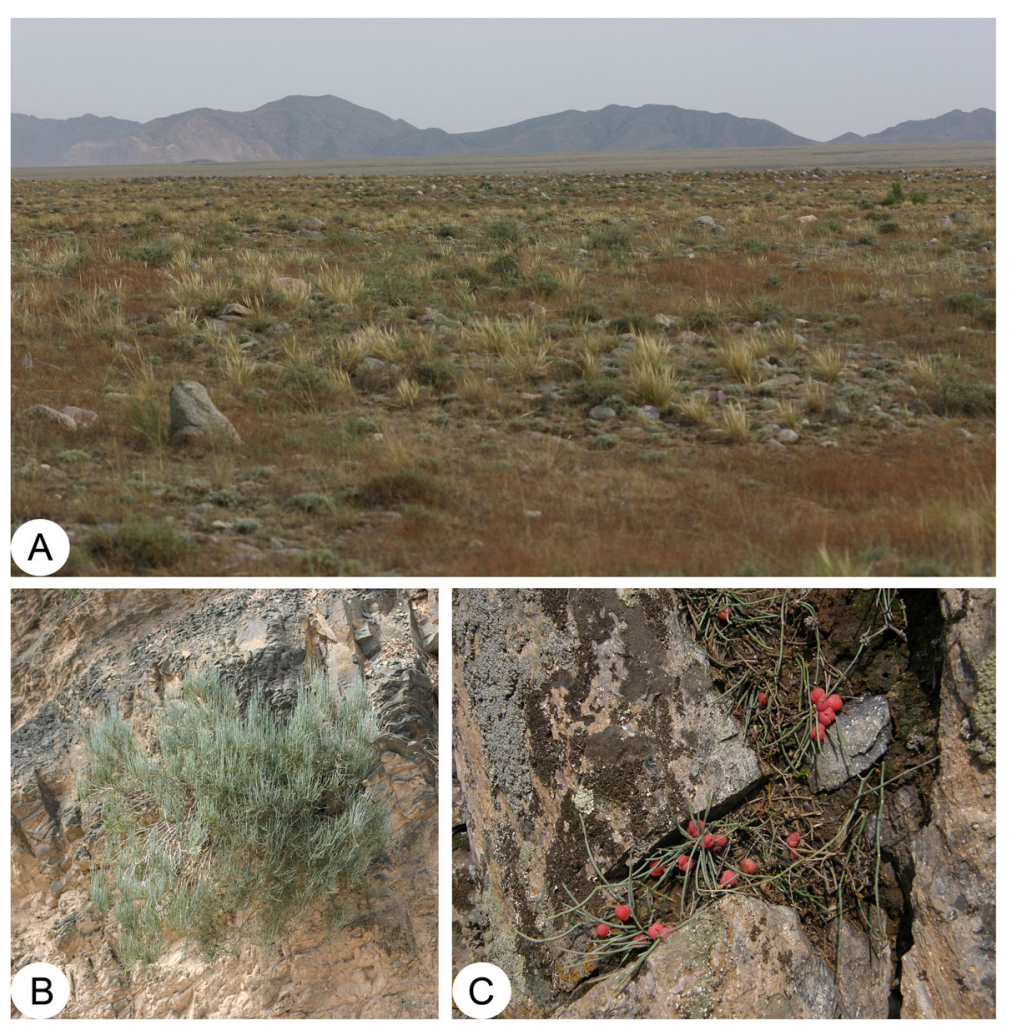

Fig. 6 Habitats of representative species of living Ephedra. a E. rhytidosperma Pachom. in Gobi; b E. equisetina Bunge on cliffs; c E. monosperma Gmel. ex C.A. Mey. in stony crevices 
Jianshangou Bed, Yixian Formation, suggesting a floristic similarity between the Jiufotang Formation and the Yixian Formation. Though ephedroid macrofossils are common in the Yixian Formation, they have not been reported from the younger Jiufotang Formation thus far. Our new species is thus the first ephedroid species from the Jiufotang Formation. This finding confirms the floristic similarity and continuity between the Yixian Formation and the Jiufotang Formation.

The Yixian Formation displays an enormous diversity of ephedroid plants. This early burst of Ephedraceae may have been driven by the turbulent geological environment at the time [15]. It is well known that volcanic activity was frequent in the Yixian Formation [57]. This radiation was not only observed in the gnetophytes, but also in other plant groups, insects, mammals, dinosaurs, and birds [55]. In the younger Jiufotang Formation, the environment was relatively stable [57]. The declining species diversity in the Jiufotang Formation may be attributable to local extinction.

\section{Conclusions}

Here we describe the first record of gnetophytes from the Lower Cretaceous Jiufotang Formation, Lamadong Village, Jianchang County, Liaoning Province, northeastern China. This finding demonstrates the lineage continuity of gnetophytes in western Liaoning since the Jiufotang Formation is ca. 5 Ma years younger than the Yixian Formation. This new plant Jianchangia verticillata gen. et sp. nov. also enhances our knowledge of morphological diversity in early gnetophytes. It has multiple foliar bracts, whorled at the nodes, and is distinguished from all other known ephedroid plants.

\section{Methods}

Our studied fossil was from Lamadong Village, Jianchang County, Liaoning Province, northeastern China (Fig. 7). The fossil bed belongs to the Jiufotang Formation. The Formation dates back to the Aptian, ca. 120.3 Ma [63], and is well-known for early birds, e.g. Jianchangornis microdonta Zhou \& al. [64], Bohaiornis guoi Hu \& al. [65], Schirooura lii Zhou \& al. [66], Jeholornis palmapenis O'Connor \& al. [67], Zhongornis haoae Gao \& al. [68, 69], and the dinosaur Moganopterus zhuiana Lu \& al. [70]. Plant fossils were rarely reported, and only a few gymnosperms have been recorded, e.g. Ginkgoites truncatus Li, Czekanowskia rigida Heer, and Elatocladus pinnatus Sun \& Zheng [57]. The new fossil is deposited in the National Museum of Plant History of China, Institute of Botany, Chinese Academy of Sciences, Beijing, China. The plant fossil was preserved as impressions, and is only fragmentary.

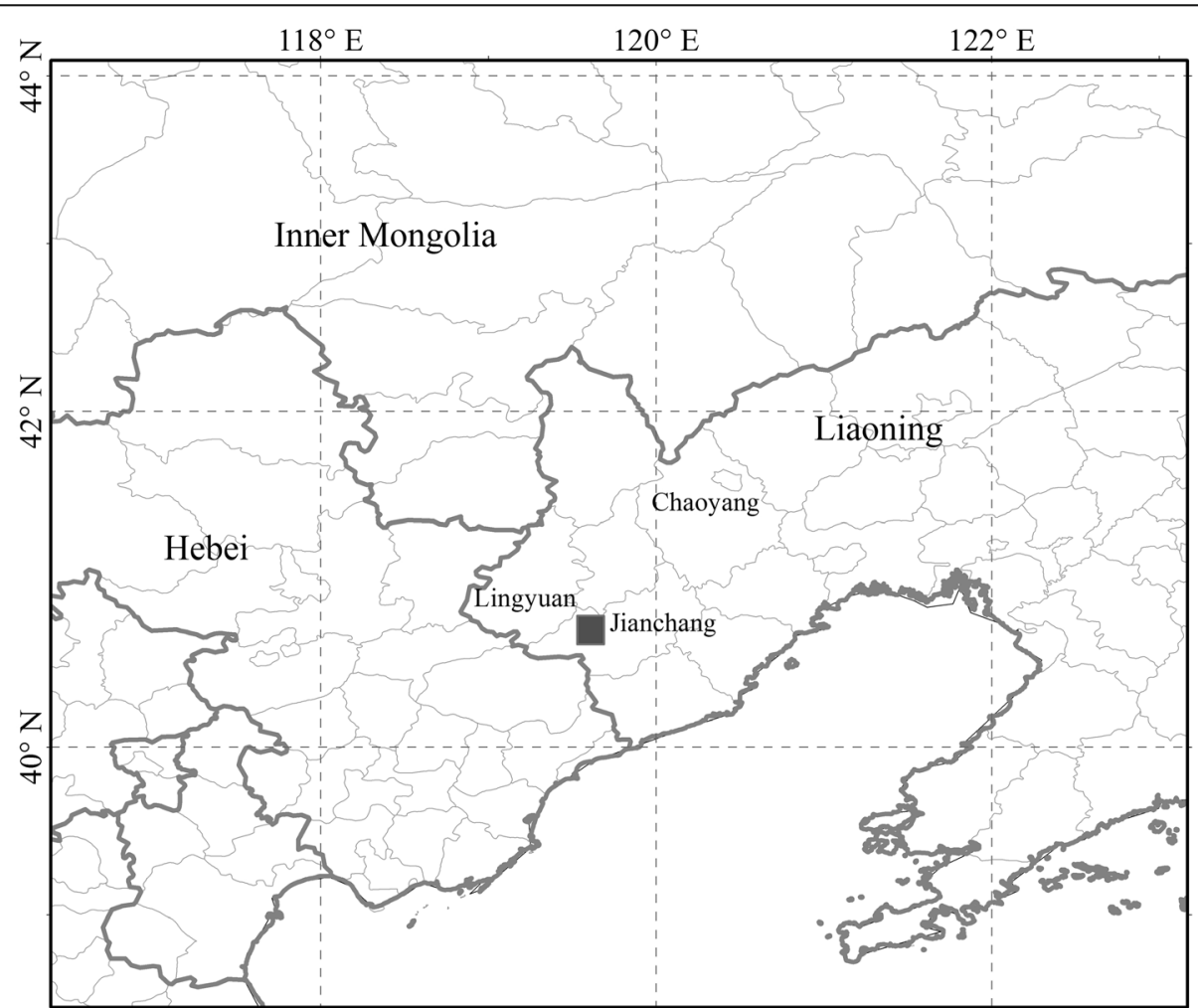

Fig. 7 Type locality of Jianchangia verticillata gen. et sp. nov. The solid square (⿶) indicates the place where the species was collected (ESRI, Redlands, CA, USA; http://www.esri.com) 
The fossil was observed with a light microscope (Nikon Eclipse E600) and was photographed with digital cameras (Nikon D700 and Olympus TG-3). The figures were manually edited and created using Adobe Photoshop CS2 ver. 9.0 and CorelDRAW X4. The map of the type locality was generated using ArcGIS 9.3 (ESRI, Redlands, CA, USA; http://www.esri.com).

\section{Abbreviations}

c: chlamydosperms; f: ovulate cone; in: internode; l: parallel-veined leaves/ bracts; mt: micropylar tube; n: node; w1: proximal whorl of bracts; w2: distal whorl of bracts

\section{Acknowledgements}

We thank Ms. A.L. Li for her kind help on line-drawing reconstruction of the fossil plant, J.A. Doyle and an anonymous reviewer for their valuable suggestions. We are also grateful to Li Wang of Xishuangbanna Tropical Botanical Garden, Chinese Academy of Sciences for his kind help in preparing the diagram in Fig. 2

\section{Authors' contributions}

YY \& YWW studied the fossil plants; YY took photos and prepared figures; $Y Y$ \& DF drafted the manuscript. All authors read and approved the final manuscript.

\section{Funding}

This work was supported by the National Natural Science Foundation of China [31470301 \& 31770211].

\section{Availability of data and materials}

All data and materials used in this study are included in this published article.

\section{Ethics approval and consent to participate}

Not applicable.

\section{Consent for publication}

Not applicable.

\section{Competing interests}

The authors declare that they have no competing interests.

\section{Author details}

'State Key Laboratory of Systematic and Evolutionary Botany, Institute of Botany, Chinese Academy of Sciences, Beijing 100093, China. ${ }^{2}$ Beijing Botanical Garden, Institute of Botany, Chinese Academy of Sciences, Beijing 100093, China. ${ }^{3}$ Department of Paleontology, University of Vienna, 1090 Vienna, Austria.

Received: 11 April 2019 Accepted: 19 December 2019 Published online: 04 February 2020

\section{References}

1. Yang $Y$, Wang Z ZH, Xu XT. Taxonomy and distribution of global gymnosperms. Shanghai: Shanghai Science \& Technology Press; 2017.

2. Bierhorst DW. Morphology of vascular plants. New York: Macmillan Company; 1971.

3. Chamberlain CJ. Gymnosperms, structure and evolution. Chicago: Chicago University Press; 1935.

4. Cutler HC. Monograph of the north American species of the genus Ephedra. Ann Missouri Bot Gard. 1939:26:373-428.

5. Gifford EM, Foster AS. Morphology and evolution of vascular plants. New York: W. H. Freeman and Company; 1989

6. Maheshwari P, Vasil V. Gnetum. New Delhi: Council Sci Industr Res; 1961

7. Markgraf F. Gnetales. In: Engler A, Prantl K, editors. Die natürlichen pflanzenfamilien, Band 13. Leipzig: Wilhelm Englemann; 1926. p. 407-41.

8. Martens P. Les gnétophytes. Berlin: Gebrüder Borntraeger; 1971.

9. Pearson HHW. Gnetales. Cambridge: Cambridge University Press; 1929.
10. Endress PK. Structures and function of female and bisexual organ complexes in Gnetales. Int J Plant Sci. 1996:157(Suppl 6):S113-25.

11. Takaso T. A developmental study of the integument in gymnosperms 3 . Ephedra distachya L. and E. equisetina Bge. Acta Bot Neerl. 1985:34:33-48.

12. Takaso T, Bouman F. Ovule and seed ontogeny in Gnetum gnemon L. Bot Mag. 1986;99:241-66.

13. Yang Y. Ontogenetic and metamorphic patterns of female reproductive organs of Ephedra sinica Stapf (Ephedraceae). Acta Bot Sin. 2001:43:1011-7.

14. Yang Y. Ontogeny of triovulate cones of Ephedra intermedia and origin of the outer envelope of ovules of Ephedraceae. Amer J Bot. 2004;91:361-8.

15. Yang Y, Ferguson DK. Macrofossil evidence unveiling evolution and ecology of early Ephedraceae. Perspect Plant Ecol Evol Syst. 2015;17:331-46.

16. Yang Y, Lin LB, Wang Q. Chengia laxispicata gen. et sp. nov., a new ephedroid plant from the Early Cretaceous Yixian Formation of western Liaoning, Northeast China: evolutionary, taxonomic, and biogeographic implications. BMC Evol Biol. 2013;13:72 http://www.biomedcentral.com/1471-2148/13/72.

17. Braukmann TWA, Kuzmina M, Stefanovic S. Loss of all plastid ndh genes in Gnetales and conifers: extent and evolutionary significance for the seed plant phylogeny. Curr Genet. 2009;55:323-37.

18. Gugerli F, Sperisen C, Büchler U, Brunner I, Brodbeck S, Palmer JD, Qiu YL. The evolutionary split of Pinaceae from other conifers: evidence from an intron loss and a multigene phylogeny. Mol Phylogenet Evol. 2001;21:167-75.

19. Ran JH, Shen $\Pi$, Wang MM, Wang XQ. Phylogenomics resolves the deep phylogeny of seed plants and indicates partial convergent or homoplastic evolution between Gnetales and angiosperms. Proc R Soc B. 2018;285 20181012. https://doi.org/10.1098/rspb.2018.1012.

20. Wan T, Liu ZM, Li LF, Ar L, Leitch IJ, Lohaus R, Liu ZJ, Xin HP, Gong YB, Liu Y, Wang WC, Chen LY, Yang Y, Kelly L, Yang J, Huang JL, Li Z, Liu P, Zhang L, Liu HM, Wang H, Deng SH, Liu M, Li J, Ma L, Liu Y, Lei Y, Xu W, Wu LQ, Liu F, Ma Q, Yu XR, Jiang Z, Zhang GQ, Li SH, Li RQ, Zhang SZ, Wang QF, van der Peer Y, Zhang JB, Wang XM. A genome for gnetophytes and early evolution of seed plants. Nat Plants. 2018:4:82-9. https://doi.org/10.1038/s41477-017-0097-2.

21. Lu Y, Ran JH, Guo DM, Yang ZY, Wang XQ. Phylogeny and divergence times of gymnosperms inferred from single-copy nuclear genes. PLoS One. 2014; 9(9):e107679. https://doi.org/10.1371/journal.pone.0107679.

22. Wang XQ, Ran JH. Evolution and biogeography of gymnosperms. Mol Phylogenet Evol. 2014;75:24-40.

23. Xi Z, Rest JS, Davis CC. Phylogenomics and coalescent analyses resolve extant seed plant relationships. PLoS One. 2013;8(11):e80870. https://doi. org/10.1371/journal.pone.0080870.

24. Krassilov VA, Dilcher DL, Douglas JG. New ephedroid plant from the lower cretaceous Koonwarra fossil bed, Victoria, Australia. Alcheringa. 1998;22:123-33.

25. Friis EM, Pedersen KR, Crane PR. Welwitschioid diversity in the early cretaceous: evidence from fossil seeds with pollen from Portugal and eastern North America. Grana. 2014:53:175-96.

26. Rydin C, Pedersen KR, Crane PR, Friis EM. Former diversity of Ephedra (Gnetales): evidence from early cretaceous seeds from Portugal and North America. Ann Bot. 2006;98:123-40.

27. Crane PR, Upchurch GR. Drewria potomacensis gen. et sp. nov., an early cretaceous member of Gnetales from the Potomac group of Virginia. Amer J Bot. 1987:74:1722-36.

28. Rothwell GW, Stockey RA. Evolution and phylogeny of gnetophytes: evidence from the anatomically preserved seed cone Protoephedrites eamesii gen. et sp. nov. and the seeds of several Bennettitalean species. Int J Plant Sci. 2013;174:511-29.

29. Cladera G, Del Fueyo GM, de Seoane LV, Archangelsky S. Early Cretaceous riparian vegetation in Patagonia, Argentina. Rev Mus Argentino Ciénc Nat ns. 2007:9:49-58.

30. Dilcher DL, Bernardes-de-Oliveira ME, Pons D, Lott TA. Welwitschiaceae from the lower cretaceous of northeastern Brazil. Amer J Bot. 2005:92:1294-310.

31. Kunzmann L, Mohr BAR, Bernardes-de-Oliveira MEC. Cearania heterophylla gen. nov. et sp. nov., a fossil gymnosperm with affinities to the Gnetales from the early cretaceous of northern Gondwana. Rev Palaeobot Palynol. 2009:158:193-212.

32. Kunzmann L, Mohr BAR, Wilde V, Bernardes-de-Oliveira MEC. A putative gnetalean gymnosperm Cariria orbiculiconiformis gen. Nov. et spec.Nov. from the early cretaceous of northern Gondwana. Rev Palaeobot Palynol. 2011;165:75-95

33. Löwe SA, Mohr BAR, Coiffard C, Bernardes-de-Oliveira MEC. Friedsellowia gracilifolia gen. Nov. et sp. nov., a new gnetophyte from the lower cretaceous Crato formation (Brazil). Palaeontographica Abt. B. 2013;289:139-77. 
34. Mohr BAR, Bernardes-de-Oliveira BEC, Loveridge RF. The macrophyte flora of the Crato formation. In: Martill DM, Bechly G, Loveridge RF, editors. The Crato fossil beds of Brasil: window into an ancient world. New York: Cambridge University Press; 2007. p. 537-65.

35. Puebla GG, Iglesias A, Gómez MA, Prámparo MB. Fossil record of Ephedra in the lower cretaceous (Aptian), Argentina. J Plant Res. 2017;130:975-88.

36. Ricardi-Branco F, Torres M, Tavares SS, de Souza Cl, Tavares PGE, Campos ACA. Itajuba yansanae gen and sp nov of Gnetales, Araripe Basin (AlbianAptian) in Northeast Brazil. In: Zhang YZ, Ray P, editors. Climate change and regional/local responses: InTech; 2013. p. 187-205. https://doi.org/10.5772/ 55704. Available from: http://www.intechopen.com/books/climate-changeand-regional-local-responses/itajuba-yansanae-gen-and-sp-nov-of-gnetalesararipe-basin-albian-aptian-in-northeast-brazil. Accessed 22 May 2013.

37. Rydin C, Mohr B, Friis EM. Cratonia cotyledon gen. et sp. nov.: a unique Cretaceous seedling related to Welwitschia. Proc Roy Soc London. 2003; 270(Suppl):S29-32.

38. Guo SX, Sha JG, Bian LZ, Qiu YL. Male spike strobiles with Gnetum affinity from the early cretaceous in western Liaoning, Northeast China. J Syst Evol. 2009;47:93-102.

39. Guo SX, Wu XW. Ephedrites from latest Jurassic Yixian formation in western Liaoning, Northeast China. Acta Palaeontol Sin. 2000;39:81-91.

40. Krassilov VA. Early cretaceous flora of Mongolia. Palaeontogr Abt B. 1982; 181:1-43.

41. Krassilov VA. Diversity of Mesozoic gnetophytes and the first angiosperms. Paleontol J. 2009;43:1272-80.

42. Liu HM, Ferguson DK, Hueber FM, Li CS, Wang YF. Taxonomy and systematics of Ephedrites cheniae and Alloephedra xingxuei (Ephedraceae). Taxon. 2008:57:577-82.

43. Liu HM, Ferguson DK, Li CS, Wang YF. New plants of Gnetales from early cretaceous of China, and its bearing on the early evolution of Ephedraceae and Welwitschiaceae in Gnetales. Chin Sci Bull. 2013;58(Suppl 1):200-9.

44. Liu ZJ, Wang X. An enigmatic Ephedra-like fossil lacking micropylar tube from the Lower Cretaceous Yixian Formation of Liaoning, China. Palaeoworld. 2016;25:67-75. https://doi.org/10.1016/j.palwor.2015.07.005

45. Rydin C, Friis EM. A new Early Cretaceous relative of Gnetales: Siphonospermum simplex gen. et sp. nov. from the Yixian Formation of Northeast China. BMC Evol Biol. 2010;10:183 http://www.biomedcentral. com/1471-2148/10/183.

46. Rydin C, Wu SQ, Friis EM. Liaoxia Gnetales: ephedroids from the early cretaceous Yixian formation in Liaoning, northeastern China. Plant Syst Evol. 2006;262:239-65.

47. Sun G, Zheng SL, Dilcher DL, Wang YD, Mei SW. Early angiosperms and their associated plants from western Liaoning, China. Shanghai: Shanghai Scientific and Technological Education Publishin House; 2001.

48. Tao JR, Yang Y. Alloephedra xingxueii gen. et sp. nov., an early cretaceous member of Ephedraceae from Dalazi formation in Yanji Basin, Jilin Province of China. Acta Palaeontol Sin. 2003;42:208-15.

49. Wang $X$, Zheng SL. Whole fossil plants of Ephedra and their implications on the morphology, ecology and evolution of Ephedraceae Gnetales. Chin Sci Bull. 2010:55:675-83.

50. Wu SQ. A preliminary study of the Jehol flora from western Liaoning. In: Chen PJ, Jin F, editors. Jehol biota. Hefei: Anhui Science and Technology Press; 1999. p. 7-57.

51. Yang Y, Geng BY, Dilcher DL, Chen ZD, Lott TA. Morphology and affinities of an early cretaceous Ephedra (Ephedraceae) from China. Amer J Bot. 2005;92: 231-41

52. Yang $Y$, Lin LB, Ferguson DK. Parallel evolution of leaf morphology in gnetophytes. Org Divers Evol. 2015;15:651-62.

53. Yang $Y$, Lin LB, Ferguson DK, Wang YW. Macrofossil evidence unveiling evolution of male cones in Ephedraceae (Gnetidae). BMC Evol Biol. 2018;18: 125. https://doi.org/10.1186/s12862-018-1243-9.

54. Yang $Y$, Wang Q. The earliest fleshy cone of Ephedra from the early cretaceous Yixian formation of Northeast China. PLoS One. 2013;8(1):e53652.

55. Chang SC, Gao KQ, Zhou CF, Jourdan F. New chronostratigraphic constraints on the Yixian formation with implications for the Jehol biota. Palaeogeogr Palaeoclimatol Palaeoecol. 2017:487:399-406.

56. Meng FX, Gao S, Liu XM. U-Pb zircon geochronology and geochemistry of volcanic rocks of the Yixian formation in the Lingyuan area, western Liaoning, China. Geolog Bull China. 2008;27:364-73.

57. Pan YQ, Gao FL, Zhang GR, Wang X, Wu ZJ. New discovery of phytolith from Jiufotang formation in Xiaotaizi area, Liaoning Province. Geol Resources. 2015;24:87-92.
58. Wang X, Zheng SL. The earliest normal flower from Liaoning Province, China. J Integr Plant Biol. 2009:51:800-11.

59. Yang $Y$, Lin LB, Ferguson DK, Zhang SZ, Wan T. A new gnetalean macrofossil from the early cretaceous and its evolutionary significance. Cretac Res. 2017;74:56-64.

60. Mussayev IF. On geography and phylogeny of some representatives of the genus Ephedra L. Bot Zhurn. 1978;63:523-43.

61. Chen JR, Funston AM. Haloragaceae. In: Wu ZY, Raven PR, Hong DY editors. Flora of China. 13. St. Louis: Missouri Botanical Garden \& Beijing: Science Press; 2007. p. 428-432.

62. Chen JR, Funston AM. Hippuridaceae. In: Wu ZY, Raven PR, Hong DY editors. Flora of China. 13. St. Louis: Missouri Botanical Garden \& Beijing: Science Press; 2007. p. 433.

63. Pan $Y H$, Sha JG, Zhou ZH, Fursich FT. The Jehol biota: definition and distribution of exceptionally preserved relicts of a continental early cretaceous ecosystem. Cretac Res. 2013;44:30-8.

64. Zhou ZH, Zhang FC, Li ZH. A new basal ornithurine bird (Jianchangornis microdonta gen. et sp. nov.) from the lower cretaceous of China. Vert. Palasiat. 2009;47:299-310.

65. Hu DY, Li L, Hou LH, Xu X. A new enantiornithine bird from the lower cretaceous of western Liaoning, China. J Vertebr Paleontol. 2011;31:154-61.

66. Zhou S, Zhou ZH, O'Connor JK. A new basal beaked ornithurine bird from the lower cretaceous of western Liaoning, China. Vert Palasiat. 2012;50:9-24

67. O'Connor JK, Sun CK, Xu X, Wang XL, Zhou ZH. A new species of Jeholornis with complete caudal integument. Hist Biol. 2012;24:29-41.

68. Rashid DJ, Surya K, Chiappe LM, Carroll N, Garrett KL, Varghese B, Bailleul A, O'Connor JK, Chapman SC, Horner JR. Avian tail ontogeny, pygostyle formation, and interpretation of juvenile Mesozoic specimens. Sci Rep. 2018; 8:9014. https://doi.org/10.1038/s41598-018-27336-X.

69. Gao CL, Chiappe LM, Meng QJ, O'Connor JK, Wang XR, Cheng XD, Liu JY. A new basal lineage of early cretaceous birds from China and its implications on the evolution of the avian tail. Palaeontol. 2008;51:775-91.

70. Lu JC, Pu HY, Xu L, Wei XF. Largest toothed pterosaur skull from the early cretaceous Yixian formation of western Liaoning, China, with comments on the family Boreopteridae. Acta Geol Sin. 2017:86:287-93.

\section{Publisher's Note}

Springer Nature remains neutral with regard to jurisdictional claims in published maps and institutional affiliations.

Ready to submit your research? Choose BMC and benefit from:

- fast, convenient online submission

- thorough peer review by experienced researchers in your field

- rapid publication on acceptance

- support for research data, including large and complex data types

- gold Open Access which fosters wider collaboration and increased citations

- maximum visibility for your research: over $100 \mathrm{M}$ website views per year

At $\mathrm{BMC}$, research is always in progress.

Learn more biomedcentral.com/submissions 